\title{
Linking digitalization and human capital to shape supply chain integration in omni-channel retailing
}

DOI:

10.1108/IMDS-09-2020-0526

\section{Document Version}

Accepted author manuscript

Link to publication record in Manchester Research Explorer

\section{Citation for published version (APA):}

Song, S., Shi, X., Song, G., \& Huq, F. A. (2021). Linking digitalization and human capital to shape supply chain integration in omni-channel retailing. Industrial Management and Data Systems. https://doi.org/10.1108/IMDS-092020-0526

\section{Published in:}

Industrial Management and Data Systems

\section{Citing this paper}

Please note that where the full-text provided on Manchester Research Explorer is the Author Accepted Manuscript or Proof version this may differ from the final Published version. If citing, it is advised that you check and use the publisher's definitive version.

\section{General rights}

Copyright and moral rights for the publications made accessible in the Research Explorer are retained by the authors and/or other copyright owners and it is a condition of accessing publications that users recognise and abide by the legal requirements associated with these rights.

\section{Takedown policy}

If you believe that this document breaches copyright please refer to the University of Manchester's Takedown Procedures [http://man.ac.uk/04Y6Bo] or contact uml.scholarlycommunications@manchester.ac.uk providing relevant details, so we can investigate your claim.

\section{OPEN ACCESS}




\title{
ACCEPTED, PRE-PRINTED VERSION
}

For citations, please refer to the published version:

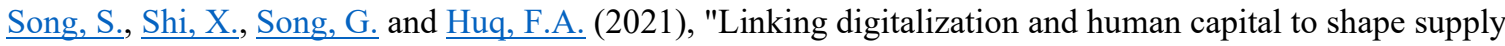
chain integration in omni-channel retailing", Industrial Management \& Data Systems, Vol. ahead-of-print No. ahead-of-print. https://doi.org/10.1108/IMDS-09-2020-0526

\section{Linking digitalization and human capital to shape supply chain integration in omni-channel retailing}

\begin{abstract}
Purpose: Supply chain integration (SCI) is key to implementing omni-channel retailing (OCR) strategy. In this paper, we explore the role of digitalization as a driver of SCI, as well the role of human capital (HC) in digitalization, using a knowledge management (KM) perspective.
\end{abstract}

Methodology/Approach: An empirical study was conducted using survey research. A sample of 188 omnichannel retailers in the Chinese market was analyzed using factor analysis and structured equation modeling (SEM) to examine the hypotheses presented in the conceptual model.

Findings: This study reveals that $\mathrm{HC}$ is positively related to the level of a firm's digitalization in OCR, and that digitalization is positively related to the retailer's SCI. Moreover, we found that employees' capital has a greater impact on digitalization than managers' capital, while digitalization has a stronger driving effect on internal and customer integration.

Research Limitations/Implications: The findings suggest that although digitalization requires retailers to accept the long-term investment challenges, it has a significant positive effect on the key of OCR strategy implementation, i.e. SCI. The findings also provide evidence for the application of KM in OCR, as this theoretical lens enriches our understanding of the phenomena of SCI in OCR and provides explanation to our results by linking digitalization and $\mathrm{HC}$.

Originality/Value: Digitalization is quantified and examined in OCR. Moreover, this study reveals the importance of $\mathrm{HC}$ on the implementation of digitalization and the different effects of digitalization on each dimension of SCI.

Keywords: Digitalization, Supply chain integration, Human capital, Omni-channel retailing, Knowledge management

Paper type: Research Paper. 


\section{Introduction}

In this era of rising consumer demands and technological advances, retailers have increasingly embraced an omni-channel retailing (OCR) strategy to provide consumers with seamless shopping experience across channels (Rodríguez-Torrico et al., 2017; Shen et al., 2018). Brick-and-mortar retailers such as Macy's, Nordstrom, and Walmart are expanding their online offerings and introducing new modes, such as in-store fulfillment of online orders. Online players such as Amazon and Zalando are opening their own brick-and-mortar stores (McKinsey, 2020). However, the channel alignment is a complex task because the challenges of selling through multiple channels will be made increasingly complex by innovation in shoppable formats, and will require greater holistic, end-to-end visibility of supply chains (Chopra, 2016; Rai et al., 2019). Only the joint efforts of every operation process in an entire supply chain enable the flow of information and goods to become as efficient, flexible, fast and cost effective (Cai et al., 2020). Therefore, supply chain integration (SCI) is key to a truly seamless OCR strategy.

In the context of OCR, the growing connectivity of devices, advances in artificial intelligence and automation all present the opportunity for more seamless supply chain integration (Huq, 2021). For example, retailers can use Big Data analytics to facilitate a streamlined and holistic view of customer behavior across all channels, or blockchain to foster mutual trust and long-term commitment among supply chain partners (Bain, 2020). Some big retailing brands, such as Amazon, views digital tools as core to its mission to get ever closer to their supply chain partners as well as consumers, spending a heavy proportion of their revenues on digital transformation. However, one study found that $84 \%$ of retailers acknowledge the need and importance for digital transformation, but on average have spent around $£ 1.5 \mathrm{~m}$ on transformation projects that have either failed or been cancelled (Aruba, 2020). The long-term investment challenge hinders the digital transformation of retailers with a mindset that demands immediate results. Therefore, exploring digitalization as the critical driver to the success of SCI of OC retailers could build confidence for retailers to accept the necessity of major digital investment.

In order to adapt to the changes brought by digitalization to the implementation of SCI of OC retailers, as the most difficult category of resource residing in firms, the importance of human capital (HC) cannot be ignored (Prajogo and Oke, 2016; Song and Song, 2021). In a recent survey, 31\% of retail managers said that a challenge of digitalization was that "it requires new skills that people don't have in our organization" (Aruba, 2020: P4) .On the one hand, OC retailers need more multi-skilled talents who understand information technology and participate in supply chain design, so as to realize precision marketing according to customer demand, as well require employees to have affinity, communication and collaboration skills. On the other hand, the implementation of advanced tech-solutions requires retailers to have the right, digitalsavvy leaders in place (Sima et al., 2020; Cai et al., 2020). Managers need to have a clear and consistent digital transformation strategy take on rapidly expanding and changing roles. Moreover, to remove employees' resistance to change, employers need to change their employees' attitude, to empower employees to accept the trends of digitalization (iScoop, 2020). Therefore, individual capabilities deserve more attention when retailers implement OCR strategy and digital transformation (Huq, 2021).

Although in practice, digitalization has brought huge changes to retailers' supply chain management (SCM), recent studies on digitalization has focused predominantly on the manufacturing and found that it leads to significant changes to manufacturing supply chains (e.g. Rakowski, 2015; Xu and Long, 2020), including the development of new products and services, operations, people and organizational management, business models, etc. Additionally, previous studies linking digitalization and human resource management 
(HRM) claimed a more capable $\mathrm{HC}$ creates more digital innovations in manufacturing sector (e.g. Sima et al., 2020; McKinsey, 2020). However, in the OC change of retail industry, such conclusions based on the manufacturing cannot be fully applicable to the retail industry because of their distinct industry characteristics. For example, compared with manufacturers, OC retailers directly target individual consumers and collaborate with many upstream distributors and suppliers (Adivar et al., 2019; McKinsey, 2020). The complex and dynamic retail supply chain network and multi channels adds difficulty to realize SCI. Another example is that digital transformation in the manufacturing industry focuses on Research \& Development and production (Roscoe et al., 2019), while in the context of OCR is marketing, in order to increase consumer satisfaction, excavate consumer behavior, and improve operational efficiency (Cai et al., 2020). Industry attributes also cause the significantly different requirements for human capabilities between manufacturing industry and the retail industry (Lee, 2017). Therefore, it is worth to further explore SCI and its potential antecedents in OCR.

The retail sector and especially its supply chains are facing drastic changes. Although the significance of SCI to the OCR strategy has been confirmed by the literature (Hübner et al., 2016; Song et al., 2019), as one of the industries most affected by digitalization, recent scholars appeal for the development of quantitative research to explore the impact of digitalization on the OCR supply chain and the role of "human" (Hagberg et al., 2016; Cai et al., 2020). Considering the considerable opportunity brought by digital transformation and the higher requirements for $\mathrm{HC}$, this paper aims to explore how to promote SCI in the context of OCR. We ask the following two research questions, by empirically identifying the relationships between HC, digitalization and SCI:

\section{RQ1. Does human capital cultivate digitalization of OC retailers?}

RQ2. Does digitalization positively influence SCI in the context of OCR?

Knowledge is a fundamental strategic asset that contributes to the improvement and success of supply chains (Attia and Eldin, 2018). In this study, the view of knowledge management (KM) is applied for the following reasons. First, with the rapid change of customer requirements and the shortening lead time of products, organizations depend on the active participation of partners in the supply chain and sharing their needed knowledge to maintain competitive advantage (Attia and Eldin, 2018). Therefore, SCI can be considered as the strategic objective of KM. Next, since digital infrastructures help organizations to gather, structure, transfer or apply explicit knowledge through integrative applications and allows the exchange of tacit knowledge through interactive applications (Schniederjans et al., 2019), a digitalization-based solution may help to achieve SCI. Last, "people" are the main drivers of KM, as KM relies on cognitive processes exercised by the human brain and involves socio-cultural interactions that digital technologies remain unable to capture (Rojas et al., 2017). Fully extracting knowledge from the connections provided by digitalization depends on human intervention (Roscoe et al., 2019).

Our study intends to contribute to the OCR supply chain research and practice by examining the relationships among $\mathrm{HC}$, digitalization and $\mathrm{SCI}$ of $\mathrm{OC}$ retailers from the theoretical perspective of $\mathrm{KM}$. An important contribution of this study is the confirmation of digitalization as the main driver of SCI in the context of OCR, bringing retailers confidence to approach the long-term investment challenge of digital transformation. It also provides evidence to support the application of KM perspective in the novel era, as KM perspective provides a new insight to the conceptual model and the explanation of results. Additionally, we also uncovered some interesting and surprising results, compared with prior studies. For instance, we 
reveal that digitalization contributes most to internal integration, suggesting retailers should first pay attention to the development of related digital technologies for internal integration to get a faster return. We also suggest that OC retailers should exert more effort in developing employees' capital (compared to manager's) to facilitate the application of digitalization, since our results expose that employees' capital have a greater impact on digitalization.

The remainder of this study is organized as follows. Section 2 reviews and categorizes related publications (e.g., journal articles, theses, and internet reports). Section 3 discusses the conceptual models of $\mathrm{HC}$, digitalization, and SCI and puts forth various hypotheses. Section 4 describes the analysis process and the results of this study's empirical research. Section 5 presents a discussion on this study's empirical results as well as its theoretical and managerial implications. Section 6 considers the limitations as well as possible future directions.

\section{Literature Review}

\section{Digitalization}

Digitalization is defined as the process of transforming an organization from a traditional to a new way of working and thinking by using digital, social, mobile, and emerging technologies (Burnson, 2018). Several existing studies have qualitatively confirmed the positive role of digitalization in fostering a stronger competitive edge. For example, Rakowski (2015) addressed how technology drives a new wave of productivity through the digitalization of key organizational and financial processes. Furthermore, for the framework and measurement of digitalization, a few of literature offer contributions. Schniederjans et al. (2019) linked KM with digitalization and put forth three pillars when implementing digitalization: technology, process, and people. Büyüközkan and Göçer (2018) presented a comprehensive framework in which digitalization was divided into five parts, namely digital strategy, digital organization/culture, digital product/service, digital operation, and digital customer experience.

A few recent studies have stated that digitalization has also brought benefits to OC retailers such as the redesign of cross-channel inventory policies and customer information databases, and the establishment of consistency in customer service (Adivar et al., 2019, Li et al., 2019). Figure 1 shows the main application of digitalization in OCR supply chain. Although interest in digitalization has been stimulated worldwide, there is still lack of quantitative research regarding the role of digitalization in OCR supply chain management.

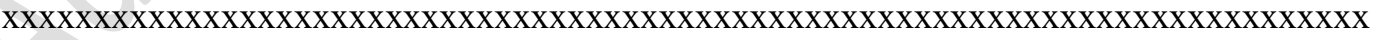 Take in Figure 1

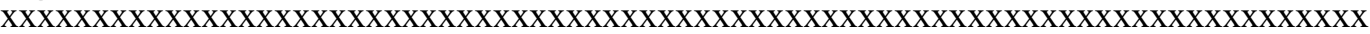

\section{Human Capital in Digitalization}

Management literature described HC as the sum of managers' and employees' skill, attitude, and interrelationship (Jin et al., 2010; Flothmann et al., 2018). Managers are responsible for decision making and play a strategic role in the organization (Porter, 1980). Their specialized and analytical abilities within his or her specialty are important for making the right decisions, as well the ability to work effectively with people is essential for developing group collaboration (Benson et al., 1991). Employees on the other hand 
are responsible for the implementation of decisions and play a practical role in the organization. Employees' business capability, problem-solving skills, operations knowledge, and creativity provide firms with distinct competencies (Levy and Murnane, 2004; Youndt et al., 1996). Moreover, when employees have strong interpersonal relationships with coworkers and external partners, trust among them enables employees to bemore willing to share knowledge with coworkers and external partners.

Previous researchers have reached a consensus that $\mathrm{HC}$ is the key resource needed to support the efficient use of digitalization. For example, Kosmol et al. (2019) considered people's capabilities as a key factor in determining the success of digitalization because people and digital technology go hand-in-hand. The main reason explained by scholars, such as Kornelakis and Petrakaki (2020), is that if firms are to catch up in the digital transformation race, it needs to overcome employees' skill gaps and scarce leadership capabilities (Sima et al., 2020; Zhou et al., 2020).

Despite several contributions about the relationships between $\mathrm{HC}$ and digitalization, there are still research gap that should be filled. As a specific industry in which the level of digitalization is high, OCR also has already generated higher requirements for HC (Kosmol et al., 2019), as they need to participate in digital transformation in different channel scenarios that have distinct characteristics. However, few studies quantitatively addressed the effects of $\mathrm{HC}$ on digitalization from the context of OCR. Therefore, we measure $\mathrm{HC}$ from the perspectives of managers and employees separately to consider the roles of the different actors on $\mathrm{OC}$ retailers' digitalization.

\section{Digitalization in Supply Chain Integration}

As current competition is among supply chains and not between individual organizations, SCI is the key to gain competitive advantages (Song et al., 2019). OCR is characterized by operations with continuous information exchange, joint operations, and supply chain network across channels that enable a conflation of the order fulfillment process (Hübner et al., 2016). Therefore, the realization of OCR requires not only the internal integration of retailers, but also the joint efforts with other entities within the whole supply chain (Cai et al., 2020). First, internal integration facilitates collaboration within all the channel departments by breaking down functional barriers, including continuous information exchange, joint operations, a conflation of the order fulfillment process, integrated inventories and customer management across channels (Chen et al., 2018). Next, to deliver fast, impeccable, flexible and efficient omnichannel service retailers should maintain a stable and deep relationship with their suppliers. Supplier integration consists of a strategic collaboration between retailers and suppliers in all production activities (e.g. joint inventory decision) (Delic et al., 2019; Song and Song, 2021). Third, retailers manage their pull-based supply chain, and they need to create and deliver new value to customers (Vishal et al., 2019). Customer integration refers to the collection of individual customer data, learning about customer needs and behavior contributes to more wise operation decision-making and competitiveness improvement (Rodríguez-Torrico et al., 2017; Feyissa et al., 2019).

Prior studies (Feng and Shanthikumar, 2018; Cole et al., 2019, Yu et al., 2020) broadly linked digitalization and main issues in supply chain management (e.g. information sharing, supply chain cooperation, demand planning). For example, Feng and Shanthikumar (2018) found that manufacturing firms are now able to obtain individualized customer data to personalize the sales process, product design and service through smart devices. Only few scholars have discussed digitalization and SCI, developing propositions based on exploratory studies. For example, Shi et al. (2020) and Feyissa et al. (2019) found that digitalization is able to coordinate complex activities in a supply chain by facilitating improvement in a 
firm's collaborative and communication capabilities as well as their level of SCI. Based on the resourcebased view and organizational capability theory, Yu et al. (2020) showed supplier and customer IT systems significantly promote supplier and customer system and process integration. However, existing studies mainly focus on manufacturing industry, the effect of digitalization on SCI in OCR is still unexplored, although the importance of SCI in the implementation of OCR strategy has been confirmed (Ishfaq et al., 2016; Song et al., 2019).

\section{Knowledge Management}

Knowledge management (KM) is defined as creating, storing/retrieving, transferring, and applying knowledge inter- and intra- organizations (Alavi and Leidner, 2018). KM is considered vital to implementation of supply chain practice in a business environment characterized by rapid changes, technological advancements, changing customer needs and higher competition (Schoenherr et al., 2014). The main reason is that KM among supply chain members would lead to more effective and efficient supply chain collaborations as well as long-term survival and competitive advantage (Wilkesmann and Wilkesmann, 2018). Therefore, considering SCI represents the extent to which a company can collaborate with partners and manage its processes to achieve effective and efficient flows of products and services to the final customer (Huo, 2012), it is reasonable to explore how to better promote SCI from the KM perspective.

Apart from the broad application of KM in SCM field, KM perspective can also provide the theoretical lens to link HC and digital transformation (Büyüközkan and Göçer, 2018; Yahya and Goh, 2002). Research claimed that we are living in an era in which data is generated in huge volume with high velocity and variety (Alavi and Leidner, 2018; Attia and Eldin, 2018). Digital technologies are reshaping business operations in retail industry (Chopra, 2016; Bain, 2020; Cai and Lo, 2020), and assists routines that support KM practices within industrial applications (Wilkesmann and Wilkesmann, 2018). To fuse and make full use of online and offline, retailers need to master new skills and obtain valuable knowledge about "going digital to enhance their services" and how to deliver high-quality information and convey value (Hagberg et al., 2016; Wang and $\mathrm{Xu}, 2018$ ). Thus, human factors couldn't be ignored, as previous literature claimed that humans are the central bearers of knowledge. Human factor can be understood as support tools or practices for innovative initiatives to be implemented (Yahya and Goh, 2002). Based on the literature review, KM perspective could offer the theoretical foundation for our study to explore the relationships among HC, digitalization and SCI in the context of OCR.

\section{Hypotheses Development}

SCI requires retailers not only to manage internal knowledge, but also to absorb and acquire knowledge from external supply chain partners (Shou et al., 2018; Schniederjans et al., 2019). Based on the KM perspective, this study aims to identify the relationship between HC, digitalization, and SCI under the context of OCR. Among others, $\mathrm{HC}$ is considered as the main facilitator of $\mathrm{KM}$, digitalization provides a creative solution of KM, whereas SCI is the strategic objective of KM. This study's conceptual model is illustrated in Figure 2 and the rationale for the hypothesized model is explained below. Previous literature on SCI showed that the influence of control variables (e.g. firm age, firm size) on the level of integration is relatively weak (Oh et al., 2012; Yu et al., 2017). Moreover, there was no theoretical evidence to support the impact of firm characteristics on the degree of digitalization. Therefore, considering that adding control variables may not provide sufficient theoretical contribution in this study, control variables were not considered in the conceptual model. 


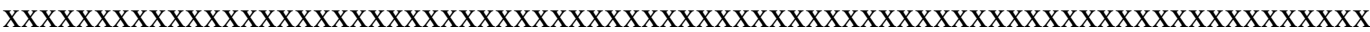

Take in Figure 2

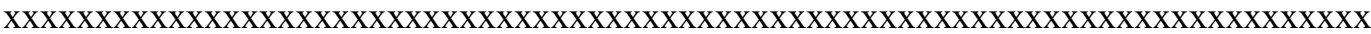

\section{Effects of HC on Digitalization}

As KM is based on the ability of a firm's members to add value to business processes through the creation, sharing, codification and integration of explicit and tacit knowledge, managers play an essential role (Büyüközkan and Göçer, 2018). Managers with digital knowledge can think up an array of creative solutions to address how to utilize digital technology to produce knowledge in a short period of time, how to convey knowledge to the growing multitude of customers in digital spaces (Batran et al., 2017). Moreover, leaders with good human skills can motivate employees to grow their careers and adapt to new trends (iSCOOP, 2020), supporting the sharing of both explicit and implicit knowledge within the organization (Chen et al., 2018). Previous literature has widely recognized that supporting top management is a critical enabler for strategic digitalization initiatives (Kosmol et al., 2019) and for digital technology use in organizations, because people engaged in key roles on digitalization initiatives ensure the collaboration between units (McKinsey, 2018), Therefore, we propose the following hypothesis:

\section{H1. Managers' capital is positively related to digitalization when retailers implement an OC strategy.}

To effectively cope with the new challenges of the digital workplace, employees must develop specific abilities, skills, knowledge, and attitudes (Park and Kim, 2018). First, retailers that have experts with rich digitalization knowledge realize the implementation of advanced tech solutions (Wang and $\mathrm{Xu}, 2018$ ). Second, employees provide services directly to customers, so employee attitudes toward work affect their timely perception of consumer demand preferences and play an important role in improving the OCR digital experience (Hagberg et al., 2016). Third, high-quality employees are more capable of knowledge identification and absorption, team cooperation and communication within organization, leading them to accept the trends of digitalization (Park and Kim, 2018). Therefore, we propose the following hypothesis:

\section{H2. Employees' capital is positively related to digitalization when retailers implement an OC strategy.}

\section{Effects of Digitalization on SCI}

Being aware of a company's knowledge management and using digital technology to strengthen it, can facilitate the internal integration (Gao et al., 2020; Wilkesmann and Wilkesmann, 2018). First, advanced information technologies can be used to systematize, enhance, and expedite large-scale internal explicit knowledge storing and transferring, enabling employees to more easily work and collaborate across channels (Attia and Eldin, 2018). Second, retailers can create a network of cross-functional teams with end-to-end accountability that features fewer barriers, improving knowledge transferring (Schniederjans et al., 2019). Third, digital technologies like AR and VR, can improve the seamless experience among channels, reflecting the application of digital knowledge in OCR (Delic et al., 2019). Then, Therefore, we propose the following hypothesis:

H3. Digitalization is positively related to the level of internal integration when retailers implement an OC strategy.

In OCR, the rapid change in customer demand and the shortening of product delivery time makes it difficult for an organization to maintain its competitive advantage. KM posits that symmetrical knowledge 
exchange between firms and suppliers, which can be achieved through digitalization, is crucial to the success of an OC strategy (Attia and Eldin, 2018). First, digitalization enables not only communication between machines but also sharing the knowledge throughout the supply chain network to keep downstream and upstream supply chain partners informed of various processes (Chen et al., 2018; Gottge et al., 2020). Second, digitalization ensures the timeliness and effectiveness of joint decision-making and knowledge sharing between retailers and suppliers especially during emergencies (Hübner et al., 2016). Third, digital technology can promote transactional authenticity and safety, fostering trust in knowledge sharing and maintaining long-term relationships on both sides (Wiengarten et al., 2019). Therefore, we propose the following hypothesis:

H4. Digitalization is positively related to the level of supplier integration when retailers implement an OC strategy.

In the context of OCR, the customer experience remains a driver of retail innovation (Rai et al., 2019). The KM perspective considers customer knowledge to be an essential issue, whose goal is to continuously improve the service experience through customer integration (Wang and $\mathrm{Xu}, 2018$ ). The use of new knowledge and technologies in the development process to significantly improve customers' purchase, delivery, and consumption patterns for products and services (Bell et al., 2017). Moreover, technology can help achieve quick response to orders and precise demand prediction by using data mining techniques to collect relevant information about the knowledge and skills needed in fast-changing retail marketing (Vishal et al., 2019). Retailers can convey knowledge to the growing multitude of customers in digital spaces as well acquire feedback based on customer knowledge, enabling them to improve product design and operational process (Aruba, 2020). Therefore, we propose the following hypothesis:

H5. Digitalization is positively related to the level of customer integration when retailers implement an OC strategy.

\section{Research Methodology}

Sampling and Data Collection

As the largest developing country and e-commerce market, the Chinese mainland presents tremendous value and potential to the retail sector. In 2019, the overall revenue of Chinese retail reached 6T USD, and comprised of $57.8 \%$ of China's economic growth. Moreover, online retail revenue totaled more than $1.46 \mathrm{~T}$ USD (Economic Daily, 2020). Moreover, both pure e-commerce and traditional retailers began establishing more diversified channels through the use of digital technologies to stimulate demand and improve their marketing advantage in China's market (MOFCOM, 2019). Therefore, analyzing a sample made up of Chinese retailers is of great significance in studying OCR.

The unit of the analysis is a retailer who is implementing OCR strategy. The sampling pool was chosen from the China General Chamber of Commerce (CGCC), which is a national trade organization registered by the Ministry of Civil Affairs of the People's Republic of China in 1994 (URL: https://www-cgcc-orgcn.vpn2.gxun.edu.cn/). Initially, after communicating with CGCC about the research objectives and the request to participate in the study, CGCC provided a list of retailers who were registered members and clearly expressed their active involvement and strong interest in OCR strategy. The final sampling pool comprised 874 retailers. The research questions include not only high-level constructs, but also the functional issues in 
operational-level. To receive valid perceptional responses, a manager (such as CEOs, directors / managing directors, and general managers) or senior staff who have worked for many years and undertake daily management tasks, such as team leader, could be the valid key informant to interpret the phenomenon under investigation (Krause et al., 2018). Moreover, considering the consuming of time and cost, the single keyrespondent survey is applied in this study (Montabon et al., 2018).

Before launching the questionnaire, we carried out the pre-test with interviews of three managers and three senior employees from OC retailers, and the necessary modifications were conducted based on their feedbacks to ensure the acceptability and understandability. Then, we conducted the survey by equestionnaires within one month using a two-wave procedure. Two weeks after the initial e-mailing, a reminder e-mail was sent to each retailer. Finally, 202 completed questionnaires were returned. After eliminating 14 responses with a substantial number of missing values and inconsistencies, we obtained 188 usable responses. The response rate of $21.5 \%$ is considered reasonable because the survey was unsolicited and involved the participation of senior management. Table 1 provides the profile of our sample retailers, showing that the sample represents a variety of industries and firm sizes. Most of our respondents were middle or top managers and had been in their positions for many years. Thus, they should be knowledgeable about their companies' activities of digital transformation and SCM.

In the questionnaire, every question was mandatory and required an answer, encouraging them to provide accurate data. With regard to non-response bias, we compared the first (62 in total) and last thirds (43 in total) of the responses on their demographic characteristics of age, annual revenue, ownership and sector type, using two approaches. The $t$-test results reveal that there is no significant statistical difference $(p>0.05)$ among the category means for the demographic characteristics. Moreover, the results of the chisquare test indicate that there is no significant difference between early and last thirds responses on all four demographic categories (i.e. age, annual revenue, ownership and sector type) based on the results of $p>0.05$. In summary, we conclude that non-response bias is not a major concern in this study.

Since there was only one respondent for each questionnaire, common method bias (CMB) might have been a problem. We applied a two-pronged approach to test the impact of CMB. First, six factors with eigenvalues higher than 1.0 were extracted based on exploratory factor analysis, explaining 77.56 percent of the total variance. The results showed that the constructs are conceptually and practically correlated. Second, the single-factor model was examined through confirmatory factor analysis, and the fit indices $\left(\chi^{2} / \mathrm{df}=9.042\right.$, RMSEA $=0.183, \mathrm{NFI}=0.561, \mathrm{CFI}=0.582)$ presented an unaccepted level. We concluded that no single factor emerged from the factor analysis and that no general factor explained the majority of the variance. Therefore, CMB was not a serious problem in this study.

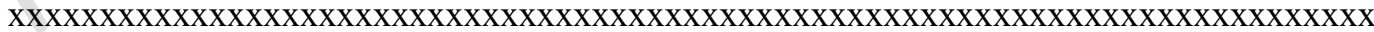

Take in Table 1

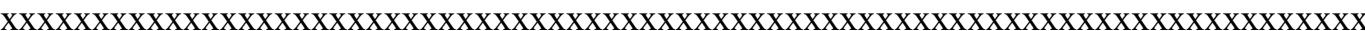

\section{Measurement of Constructs}

In this study, a comprehensive review of the studies across the fields of HRM, SCM, OCR, and digitalization in Internet reports (e.g. McKinsey, Bain) and academic researches was conducted to identify potential measures for the conceptual constructs. Consequently, 35 measured items were adopted, and the supported references are listed in Appendix. 
First, we searched the previous literature to develop valid measures for our constructs. Specifically, the measurements of managers' capital and employees' capital involve three dimensions: skills, attitudes, and interpersonal relationships (e.g. Song et al., 2020). Digitalization was measured through strategy, culture, operations, product/services, and customer experience (e.g. Kosmol et al., 2019; Büyüközkan and Göçer, 2018), and SCI was measured via internal, supplier, and customer integrations (e.g. Macarena et al., 2018). Although most of the measurement items come from existing literature, we have revised them based on the distinct characteristics of OCR supply chain. For example, HC emphasizes cross-channel departmental collaboration capabilities, and digitalization includes providing digital consumer experience. Internal integration mainly emphasizes the integration of information, process and organization across channels. Supplier integration mainly refers to the sharing of operational information (e.g. inventory information) and joint operational decision-making with suppliers. Customer integration includes not only providing customers with cross-channel products, services, and order visualization, but also receiving feedback from customers. We used a five-point Likert scale to capture respondents' perception of the levels of HC, digitalization and SCI. Each item was assessed by the strength of respondent's agreement, with "1" indicating "strongly disagree" and "5" indicating "strongly agree".

\section{Reliability and Validity}

Exploratory factor analysis was conducted to ensure the unidimensionality of the scales. A principal component factor analysis with varimax rotation was used to detect the underlying dimensions. All items had strong loadings (greater than 0.5 ) on the specific factor that they were intended to measure. Cronbach's alpha $(\alpha)$ was computed for each construct to check its internal consistency. Table 2 demonstrates that all $\alpha$ values were above 0.8 and that all composite reliability values were greater than 0.8 , thus confirming the reliability of the constructs.

Confirmatory factor analysis was conducted to assess both convergent and divergent validity. In the model used to check convergent validity, each item was linked to its corresponding construct and the covariance among constructs was freely estimated. The model fit indices were $\chi^{2}(545)=1082.370, \chi^{2} / \mathrm{df}=$ $1.986, \mathrm{RMSEA}=0.071, \mathrm{CFI}=0.909, \mathrm{GFI}=0.858, \mathrm{AGFI}=0.887, \mathrm{NFI}=0.880$, and $\mathrm{TLI}=0.931$, indicating that the model fit was acceptable. Furthermore, all factor loadings were greater than the 0.5 cutoff and all $t$ values were greater than 2.0. Therefore, convergent validity was ensured. As for discriminant validity, all inter-construct correlations were lower than the square root of the average variance (AVE) extracted for each factor, thus discriminant validity was also ensured (see Table 2).

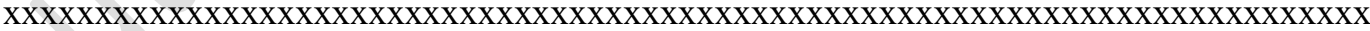 Take in Table 2}

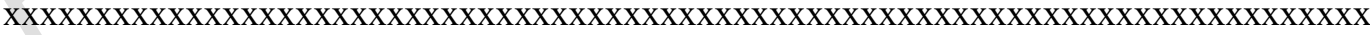

\section{Results}

Structural equation modeling (SEM) with the maximum likelihood estimation method and LISREL 8.70 software were used to estimate the relationships among the constructs. To minimize multicollinearity, the independent variables and the moderators were mean-centered (Marodin et al. 2017). Moreover, the variance inflation factors were computed, and the value of 1.83 reveals that the data set is suitable for regression analysis. The model fit indices were $\chi^{2}(550)=1043.353, \chi^{2} / \mathrm{df}=1.897, \mathrm{RMSEA}=0.059, \mathrm{CFI}=$ $0.896, \mathrm{GFI}=0.903, \mathrm{AGFI}=0.825, \mathrm{NFI}=0.891, \mathrm{TLI}=0.929$, all of which exceed the threshold values 
suggested by Hu and Bentler (1999). Figure 3 shows the SEM results with the standardized coefficients for the significant paths. Among the 5 proposed hypotheses, all are supported at the 0.001 significance level. The results show that the effects of managers' capital and employees' capital are significant, supporting H1 and $\mathrm{H} 2$. The results also indicate that digitalization has a positive effect on internal integration, supporting $\mathrm{H} 3$, as well a positive impact of digitalization on integration with suppliers and customers, supporting $\mathrm{H} 4$ and $\mathrm{H} 5$.

Furthermore, we statistically test the difference of the effects of managers' capital and employees' capital on digitalization, as well as the effects of digitalization on three dimensions of SCI. The result $\left(\Delta \chi^{2}=\right.$ $5.409, p<0.001)$ suggests that employees' capital has a greater effect on retailer digitalization ( $\mathrm{H} 2, \beta=0.526)$ than managers' capital $(H 1, \beta=0.360)$. Similarly, digitalization has the greatest impact on internal integration $(\mathrm{H} 3, \beta=0.872)$ and a minimal impact on supplier integration $(\mathrm{H} 4, \beta=0.419)$ as a result of $\Delta \chi^{2}$ (internal integration $\&$ customer integration $)=2.184(p<0.001)$ and $\Delta \chi^{2}$ (internal integration \& supplier integration) $=41.142(p<0.001)$.

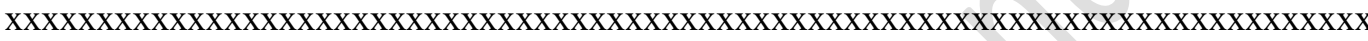

Take in Figure 3

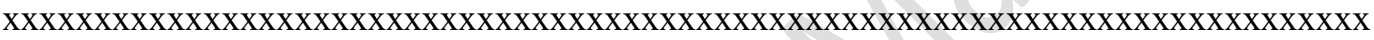

\section{Discussion and Implications}

\section{Discussion of the Results}

Our findings provide substantial empirical support for the positive relationships among HC, digitalization and SCI in the context of OCR. The study's first objective is to examine the effects of HC's two dimensions on the digitalization of OC retailers. Our findings show that both managers' capital and employees' capital have positive effect for OC retailers on digitalization, which is consistent with the views of HRM and SCM studies such as Frederico et al. (2019). However, different from the explanation of this phenomenon in existing papers, the KM perspective provides a useful theoretical lens to explain the findings in this paper. Critical portion of the knowledge and skills required for digital innovation resides with and is used by individuals, while SCI can be improved by digitalization due to the opportunities surrounding digitalization have made it possible for supply chains to access, store and process a large amount of knowledge both from within the retailer and externally. Further, our findings add to extant literature by finding that employees play a more critical role in the success of digital transformation. Considering the retail industry in China is still labor-intensive, creative and knowledgeable employees are more likely to develop new and innovative ideas (Hagberg et al., 2016).

The study's second objective is to investigate how digitalization promote retailers' SCI. Consistent with the views described in the previous studies, our findings also confirm the positive effect of digitalization on SCI. Today, knowledge is an important strategic asset. SCI relies on knowledge sharing and transferring within the whole supply chain (Schniederjans et al., 2019). Digitalization provides the opportunities to effectively implement KM inter-organizations. Thus, retailers can reap the benefits of SCI with digital transformation into SCM. Our findings also indicate that digitalization has the greatest effect on internal integration. This is an interesting finding given that, only few studies claimed organizations must first 
develop the integration intra-organizations through system, data, and process integration before they can engage in meaningful external integration (Chen et al. 2018; Zhu et al. 2018). Based on the KM perspective, data integration and knowledge integration among internal departments facilitate firms to combine prior knowledge from the repository with their newly absorbed knowledge, thereby expediting the value of the knowledge acquired in the external supply chain (Shen et al., 2019; Zhang et al., 2018). Further, as for the relatively weaker impact on supplier integration, can be explained by the characteristics of the respondents. As shown in Table 1, about $65 \%$ retailers reported that their annual revenue is over 200 million of RMB. Revenue represents market position and power to a certain extent. Therefore, in the retailer-leading supply chain, retailers can rely on their own supply chain power to achieve supplier integration, which weakens the role of digitalization.

\section{Theoretical Implications}

Our study makes significant contributions to the extant literature. On the one hand, to the best of our knowledge, this study is the first to investigate the relationships among HC, digitalization and SCI within the context of OCR. Although studies such as Büyüközkan and Göçer (2018) suggested a link between digitalization and SCM and the important role of human in supporting the successful digital transformation, mostly focusing on manufacturing industries, it was unknown whether these relationships still exist in the context of OCR. Due to the distinct characteristics between manufacturing and retailing in terms of supply chain structure, the path of digitalization, and the requirements of $\mathrm{HC}$, our study contributes to the extant literature in that it validates the positive effects of digitalization and $\mathrm{HC}$ in promoting $\mathrm{SCI}$ in the context of OCR. Thus, the findings pertaining to the relationships among HC, digitalization, and SCI extends prior research on digitalization and SCI in the context of OCR.

On the other hand, this study clarifies the main driving factors of SCI and explore the differences of driving effects based on KM, although SCI as the key to achieving successful OCR is generally considered to be certain (Murfield et al., 2017; Song et al., 2019). The theoretical lens of KM in this paper informs the development of conceptual model, where $\mathrm{HC}$ is the main facilitator, digitalization provides a creative solution, and SCI is the strategic objective, and adds explanatory power to our results (Zorzini et al., 2015). For example, our results show that HC, especially employees' capital is the main facilitator of digitalization as expedites the extraction of knowledge. Furthermore, we are able to present a more nuanced understanding of the effect of digitalization on SCI. We reveal that digitalization as a creative solution which helps organizations to gather, structure, produce, convey, and apply knowledge have varied impact on the three dimensions of SCI - internal integration, supplier integration, and customer integration. Namely, digitalization has the biggest impact on internal integration whilst there is a relatively weaker impact on supplier integration, which seems to be counterintuitive.

\section{Managerial Implications}

The managerial implications of this paper are three-fold. First, our results motivate retailers to focus on the cultivation of $\mathrm{HC}$, especially the employee level. Pursuing high level of $\mathrm{HC}$ with strong emphasis on the development activities for employees would likely improve their chances of reaping better benefits in digitalization, as the implementation of advanced tech solutions requires retailers to have the digital talents to manage the digitalization strategy. Second, the positive effect of digitalization on three dimensions of SCI has been confirmed. Thus, retailers should accept the necessity of major investment in digitalization to possess the higher level of SCI and maintain competitive advantages. Third, we also suggest retailers to pay more attention on internal integration. Retailers should adopt a series of internal digital practices (e.g. 
internal digital culture, internal digital operations, giving day-to-day tools a digital upgrade). Starting from internal digitalization, advanced technologies enable retailers to digitize and integrate resources and operations from physical and online retail channels.

\section{Conclusions, Limitations, and Future Research}

This study identifies the relationships between HC, digitalization, and SCI in the context of OCR based on a KM perspective. Some findings are consistent with theoretical expectations and the findings of previous studies in that both managers' capital and employees' capital are positively related to the level of a firm's digitalization and that digitalization is positively related to the level of SCI. Moreover, we found that employees' capital has a greater impact on digitalization than managers' capital, while digitalization has a stronger driving effect on internal integration and customer integration.

Although this study makes a significant contribution to the literature and practice, there are a few limitations that provide avenues for further research. First, the digitalization of industry is changing the roles and responsibilities of personnel, requiring transformation of Human Resource Management (HRM) functionalities (Zhou et al., 2020). Therefore, it might be an opportunity to examine the effect of HRM on SCM in the context of OCR, whereas this issue has been neglected in this study. Second, considering the issue of $\mathrm{HC}$ is about the HR level while digital transformation and SCM is about strategic level, professional respondents from different departments participate in the questionnaire in a company may provide more reliable information. Third, to obtain the most comprehensive information from the most appropriate person, multiple respondents from different functions and hierarchies should be required to complete certain sections of the questionnaire. Future studies could perform the multi-respondent survey to further improve the accuracy of the information. Finally, in this paper, we developed the conceptual model without considering of any control variables. Future studies could investigate and compare the effect of potential control variables (e.g. firm age, firm size, firm ownership) on digitalization and SCI. 


\section{References}

Adivar, B., Hüseyinoğlu, I.Ö.Y. and Christopher, M. (2019), "A quantitative performance management framework for assessing omnichannel retail supply chains", Journal of Retailing and Consumer Services, Vol. 48, pp. 257-269.

Alavi, M. and Leidner, D.E. (2018), "Review: knowledge management and knowledge management systems: conceptual foundations and research issues", MIS Quarterly, Vol. 25 No. 1, pp. 107-136

Aruba. (2020), "The road to digitalization in retailing", https://www.arubanetworks.com/assets/eo/Aruba_Retail-Tech_Report.pdf.

Attia, A. and Eldin, I.E. (2018), "Organizational learning, knowledge management capability and supply chain management practices in the Saudi food industry", Journal of Knowledge Management, Vol. 22 No. 6, pp. 1217-1242.

Bain. (2020), "The Future of Retail: Winning Models for a New Era", https://www.bain.com/contentassets/9380fbb12417471fa7c1db686aff142d/bain brief the future of $\mathrm{r}$ etail_winning_models_for_a new_era.pdf.

Batran, A., Erben, A., Schulz, R. and Sperl, F. (2017), "Procurement 4.0: a survival guide in a digital", Disruptive World, Campus, Frankfurt.

Bell, D. R., Gallino, S. and Moreno, A. (2017), "Offline showrooms in omnichannel retail: demand and operational benefits", Management Science, Vol. 64 No. 4, pp. 1629-1651.

Benson, P. G., Saraph, J. V. and Schroeder, R. G. (1991). "The effects of organizational context on quality management: An empirical investigation”, Management Science, Vol. 37 No. 9, pp. 1107-1124.

Burnson, P. (2018), "Procurement is getting its digitized act together", Supply Chain Management Review, Vol. 22 No. 1. pp. 10-11.

Büyüközkan, G. and Göçer F. (2018), "Digital supply chain: literature review and a proposed framework for future research", Computers in Industry, Vol. 97, pp. 157-177.

Chen, M., Liu, H.F., Wei, S.B. and Gu, J.B. (2018), “Top managers' managerial ties, supply chain integration, and firm performance in China: A social capital perspective", Industrial Marketing Management, Vol. 74, pp. 205-214.

Cai, Y.J. and Lo, C.K.Y. (2020), "Omni-channel management in the new retailing era: A systematic review and future research agenda", International Journal of Production Economics, Vol. 229, Doi: 10.1016/j.ijpe.2020.107729

Chopra, S. (2016), "How omni-channel can be the future of retailing", Decision, Vol. 43 No. 2, pp. 135-144.

Cole, R., Stevenson, M. and Aitken, J. (2019), "Blockchain technology: implications for operations and supply chain management", Supply Chain Management: An International Journal, https://doi.org/10.1108/SCM-09-2018-0309

Delic, M., Daniel, R.E. and Josip M. (2019), “Additive manufacturing: empirical evidence for supply chain integration and performance from the automotive industry", Supply Chain Management: An International Journal, Vol. 24 No. 5, pp. 604-621.

Economic Daily. (2020), "In 2019, the total retail sales of consumer goods reached 41.2 trillion yuan, maintaining the first driving force of economic growth for six consecutive years", Available at: http://news.youth.cn/gn/202001/t20200121_12174951.htm.

Feng, Q. and Shanthikumar, J.G. (2018), "How research in production and operations management may evolve in the era of big data", Production and Operations Management, Vol. 27 No. 9, pp. 1670-1684.

Feyissa, T.T., Sharma, R.R.K. and Lai, K.K. (2019), "The impact of the core company's strategy on the dimensions of supply chain integration", The International Journal of Logistics Management, Vol. 30, 
No. 1, pp. 231-260.

Flothmann, C., Hoberg, K. and Gammelgaard, B. (2018), "Disentangling supply chain management competencies and their impact on performance: a knowledge-based view", International Journal of Physical Distribution \& Logistics Management, Vol. 48 No. 6, pp. 630-655.

Frederico, G., Garza-Reyes, J., Anosike, A. and Kumar, V. (2019), "Supply Chain 4.0: concepts, maturity and research agenda", Supply Chain Management, Vol. 25 No. 2, pp. 262-282.

Gao, P., Zhang, J., Gong, Y. and Li, H. (2020), "Effects of technical IT capabilities on organizational agility: The moderating role of IT business spanning capability", Industrial Management \& Data Systems, Vol. 120 No. 5, pp. 941-961.

Gottge, S., Menzel, T. and Forslund, H. (2020), "Industry 4.0 technologies in the purchasing process", Industrial Management \& Data Systems, Vol. 120 No. 4, pp. 730-748.

Hagberg, J., Sundstrom, M. and Egels-Zanden, N. (2016), “The digitalization of retailing: an exploratory framework", International Journal of Retail and Distribution Management, Vol. 44 No. 7, pp. 694-712.

Hu, L.T. and Bentler, P.M. (1999), "Cutoff criteria for fit indexes in covariance structure analysis: conventional criteria versus new alternatives”, Structural Equation Modeling: A Multidisciplinary Journal, Vol. 6 No. 1, pp. 1-55.

Huo, B. (2012), "The impact of supply chain integration on company performance: an organizational capability perspective", Supply Chain Management: An International Journal, Vol. 17 No. 6, pp. 596610.

Huq, F. A. (2021). "The importance of supply chain integration to multiple channel strategies", Retail Gazette, available at: https://www.retailgazette.co.uk/blog/2021/05/sponsored-article-importancesupply-chain-integration-multiple-channel-strategies/.

Hübner, A., Wollenburg, J. and Hozapfel, A. (2016), "Retail logistics in the transition from multi-channel to omni-channel", International Journal of Physical Distribution and Logistics Management, Vol. 46 No. 6/7, pp. 562-583.

i-SCOOP. (2020), "The state of digital HR - HR transformation and talent management", https://www.iscoop.eu/digital-transformation/digital-hr/.

Ishfaq, R., Defee, C.C., Gibson, B. J. and Raja, U. (2016), "Realignment of the physical distribution process in omnichannel fulfillment", International Journal of Physical Distribution \& Logistics Management, Vol. 46 No. 6/7, pp. 543-561.

Kornelakis, A. and Petrakaki, D. (2020), "Embedding employability skills in UK higher education: Between digitalization and marketization", Ind. High. Educ, 2020.

Kosmol, T., Felix, R. and Lutz K. (2019), "You'll never walk alone: Why we need a supply chain practice view on digital procurement", Journal of Purchasing and Supply Management, Vol. 25 No. 4, DOI: 10.1016/j.pursup.2019.100553.

Krause, D., Luzzini, D. and Lawson, B. (2018). "Building the case for a single key informant in supply chain management survey research", Journal of Supply Chain Management, Vol. 54 No. 1, pp. 42-50.

Lee, H. (2017), "Personality determinants of need for interaction with a retail employee and its impact on self-service technology (SST) usage intentions", Journal of Research in Interactive Marketing, Vol. 11 No. 3, pp. 214-231.

Levy, F. and Murnane, R. J. (2004). "The new division of labor: How computers are creating the next job", Princeton, NJ: Princeton University Press.

Li, G., Zhang, T. and Tayi, G.K. (2019), "Inroad into omni-channel retailing: physical showroom deployment of an online retailer", European Journal of Operational Research, Vol. 283 No. 2, pp. 676-691. 
Macarena, S.D., Pedro, G.V. and José, M.F. (2018), "Mediating and non-linear relationships among supply chain integration dimensions", International Journal of Physical Distribution and Logistics Management, Vol. 48 No. 7, pp. 698-723.

Marodin, G. A., Tortorella, G. L., Frank, A. G. and M. G. Filho. (2017), "The moderating effect of lean supply chain management on the impact of lean shop floor practices on quality and inventory", Supply Chain Management: An International Journal, Vol. 22 No. 6, pp. 473-485.

McKinsey. (2018). "Unlocking success in digital transformations", available at: https://wenku.baidu.com/view/6985d8d585868762caaedd3383c4bb4cf6ecb70b.html (accessed 16 December 2019),

McKinsey. (2020), "Supply chain of the future: Key principles in building an omnichannel distribution network",

https://www.mckinsey.com/ /media/McKinsey/Industries/Retail/Our\%20Insights/Supply\%20chain\% 20of\%20the\%20future $\% 20 \mathrm{Key} \% 20$ principles $\% 20 \mathrm{in} \% 20 \mathrm{building} \% 20 \mathrm{an} \% 20 \mathrm{omnichannel} \% 20 \mathrm{distribu}$ tion\%20network/Supply-chain-of-the-future.ashx

MOFCOM, (2019), “China retail industry development report (2018/2019)”, http://www.comnews.cn/article/pnews/201909/20190900019040.shtml.

Montabon, F., Daugherty, P. J. and Chen, H. (2018). "Setting standards for single respondent survey design", Journal of Supply Chain Management, Vol. 54 No. 1, pp. 35-41.

Murfield, M., Boone, C.A., Rutner, P. and Thomas, R. (2017), "Investigating logistics service quality in omni-channel retailing", International Journal of Physical Distribution \& Logistics Management, Vol. 47 No. 4, pp. 263-296.

Oh, L.B., Teo, H.H. and Sambamurthy, V. (2012). "The effects of retail channel integration through the use of information technologies on firm performance", Journal of Operations Management, Vol. 30 No. 5 , pp. 368-381.

Park, S. and Kim, E.J. (2018), "Fostering organizational learning through leadership and knowledge sharing", Journal of Knowledge Management, Vol. 22, No. 6, pp. 1408-1423.

Porter, M. E. (1980). "Competitive strategy: Techniques for analyzing industries and competitors", New York: Free Press.

Prajogo, D.I. and Oke, A. (2016), "Human capital, service innovation advantage, and business performance: the moderating roles of dynamic and competitive environments", International Journal of Operations and Production Management, Vol. 36 No. 9, pp. 974-994.

Rai, H.B., Sara, V., Cathy, M., Penelope, S. and Lieselot, V. (2019), "Logistics outsourcing in omnichannel retail: State of practice and service recommendations", International Journal of Physical Distribution and Logistics Management, Vol. 49 No. 3, pp. 267-286.

Rakowski, E. (2015), “TechTrends 2016, Part internal integration: The supply chain goes digital”, available at: http://refhub.elsevier.com/S0166-3615(17)30448-7/sbref0345.

Rodríguez-Torrico, P., Cabezudo, R.S.J. and San-Martín, S. (2017), “Tell me what they are like and I will tell you where they buy: an analysis of omnichannel consumer behavior", Computers in Human Behavior, Vol. 68 No. 3, pp. 465-471.

Rojas, R., Morales, V.J., Sánchez, E. and Jiménez, A.E. (2017), "El aprendizaje colaborativo en la docencia sobre empresa. Dialnet", 235-235. https://dialnet.unirioja.es/servlet/articulo?codigo=6274710.

Roscoe, S., Cousins, P. and Handfield, R. (2019), "The micro foundations of an operational capability in digital manufacturing”, Journal of Operations Management, Vol. 65 No. 8, pp. 774-793.

Schniederjans, D.G., Carla, C. and Mehrnaz K. (2019), "Supply chain digitalization trends: An integration 
of knowledge management", International Journal of Production Economics, Vol. 220, DOI:10.1016/j.ijpe.2019.07.012.

Schoenherr, T., Griffith, D.A., Chandra, A. (2014), "Intangible capital, knowledge and new product development competence in supply chains: process, interaction and contingency effects among SMEs". International Journal of Production Research, Vol. 52 No. 16, pp. 4916-4929.

Shen, B., Choi, T.M. and Minner, S. (2019), "A review on supply chain contracting with information considerations: information updating and information asymmetry", International Journal of Production Research, Vol. 57 No. (15-16), pp. 4898-4936.

Shen, X.L., Li, Y.J., Sun, Y. and Wang, N. (2018), "Channel integration quality, perceived fluency and omnichannel service usage: the moderating roles of internal and external usage experience", Decision Support Systems, Vol. 109, pp. 61-73.

Shi, S., Wang, Y., Chen, X. and Zhang, Q. (2020), "Conceptualization of omnichannel customer experience and its impact on shopping intention: A mixed-method approach", International Journal of Information Management, Vol. 50, pp. 325-336.

Shou, Y., Hu, W. and Wu, Y. (2018), "Exploring the role of intellectual capital in supply chain intelligence integration”, Industrial Management and Data Systems, Vol. 118 No. 5, pp. 1018-1032.

Sima, V., Gheorghe, I.G., Subic, J. and Nancu, D. (2020), "Influences of the Industry 4.0 Revolution on the human capital development and consumer behavior: a systematic review”, Sustainability, Vol. 12 No. 10, Doi:10.3390/su12104035.

Song, G., Song, S. and Sun, L. (2019), "Supply chain integration in omni-channel retailing: a logistics perspective", The International Journal of Logistics Management, Vol. 30 No. 2, pp. 527-548.

Song, G. and Song, S. (2021), "Fostering supply chain integration in omni-channel retailing through human resource factors: empirical study in China's market", International Journal of Logistics Research and Applications, Vol. 24 No.1, pp.1-22.

Song, S. Shi X. and Song, G. (2020), "Supply chain integration in omni-channel retailing: a human resource management perspective", International Journal of Physical Distribution and Logistics Management, Vol. 50 No. 1, pp. 101-121.

Vishal, K.G., Ting, Q.U. and Manoj, K.T. (2019), "Multi-period price optimization problem for omnichannel retailers accounting for customer heterogeneity", International Journal of Production Economics, Vol. 212, pp. $155-167$

Wang, X. and Xu, M. (2018), "Examining the linkage among open innovation, customer knowledge management and radical innovation: The multiple mediating effects of organizational learning ability", Baltic Journal of Management, Vol. 13, No. 3, pp. 368-389.

Wiengarten, F., Li, H., Prakash, J.S. and Fynes, B. (2019), "Re-evaluating supply chain integration and firm performance: linking operations strategy to supply chain strategy", Supply Chain Management: An International Journal, Vol. 24 No. 4, pp. 540-559

Wilkesmann, M. and Wilkesmann, U. (2018), "Industry 4.0 - organizing routines or innovations", Vine Journal of Information \& Knowledge Management Systems, Vol. 48 No. 2, pp. 238-254.

$\mathrm{Xu}$, D. and Long, Y. (2020), "The role of supply chain integration in the transformation of food manufacturers: a case study from China", International Journal of Logistics Research and Applications, DOI: $10.1080 / 13675567.2020 .1729707$.

Yahya, S. and Goh, W. (2002), "Managing human resources toward achieving knowledge management", Journal of Knowledge Management, Vol. 6 No. 5, pp. 457-468.

Youndt, M. A., Snell, S. A., Dean, J. W., Jr. and Lepak, D. P. (1996). "Human resource management, 
manufacturing strategy, and firm performance", Academy of Management Journal, Vol. 39 No. 4, pp. 836-866.

Yu, W., Jacobs, M.A., Chavez, R. and Feng, M. (2017). "The impacts of IT capability and marketing capability on supply chain integration: a resource-based perspective", International Journal of Production Research, Vol. 55 No. 14, pp. 4196-4211

Yu, Y., Huo, B. and Zhang, Z. (2020), "Impact of information technology on supply chain integration and company performance: evidence from cross-border e-commerce companies in China", Journal of Enterprise Information Management, Doi:10.1108/jeim-03-2020-0101.

Zhang, M., Zhao, X. and Lyles, M. (2018), "Effects of absorptive capacity, trust and information systems on product innovation", International Journal of Operations \& Production Management, Vol. 38 No. 2, pp. 493-512.

Zhou, Y., Liu, G., Chang, X. and Wang, L. (2020), “The impact of HRM digitalization on firm performance: investigating three-way interactions", Asia Pacific Journal of Human Resources, Doi:10.1111/17447941.12258 .

Zhu, Q., Krikke, H. and Marjolein, C.J.C. (2018), "Supply chain integration: value creation through managing inter-organizational learning”, International Journal of Operations \& Production Management, Vol. 38 No. 1, pp. 211-229.

Zorzini, M., Hendry, L.C., Huq, F. A. and Stevenson, M. (2015), "Socially responsible sourcing: reviewing the literature and its use of theory", International Journal of Operations \& Production Management, Vol. 35 No. 1, pp. 60-109. 


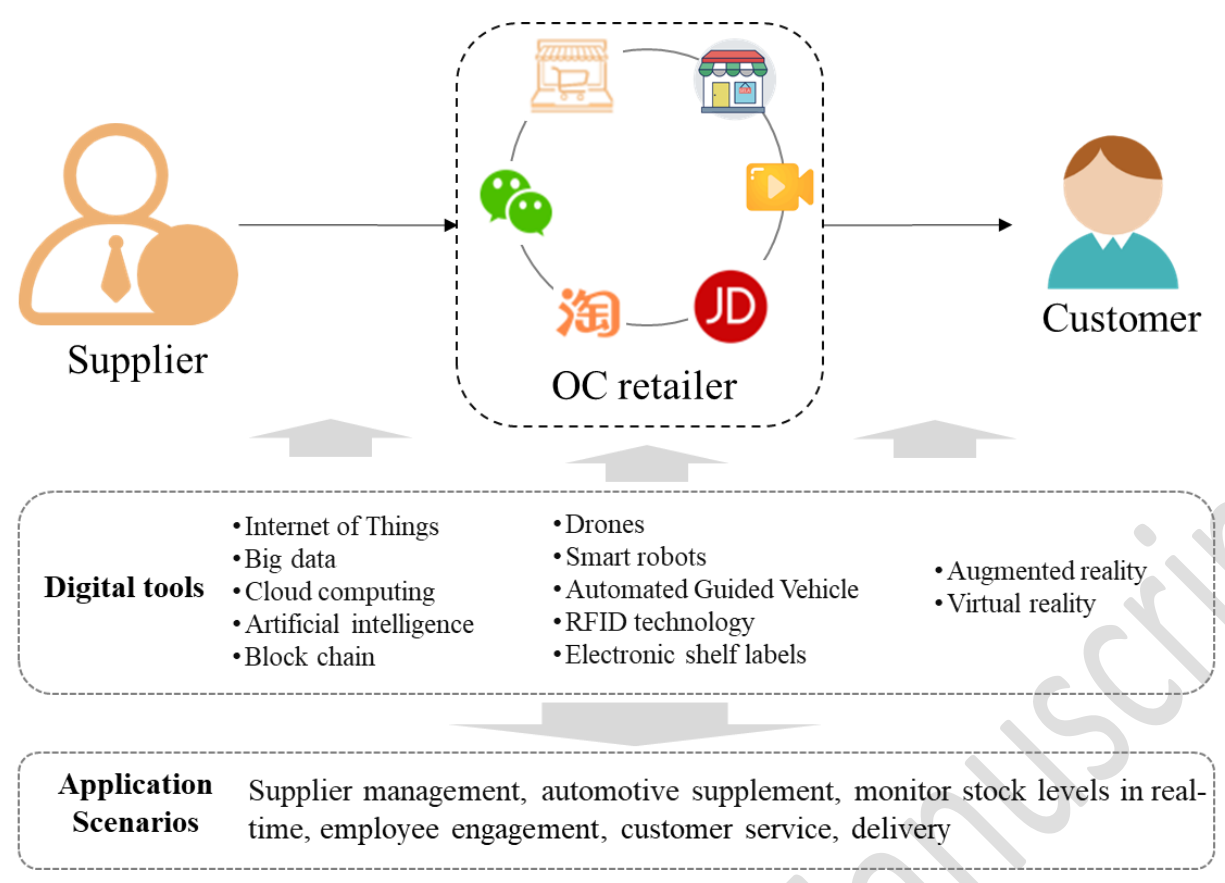

Figure 1. The Digital Application in OCR

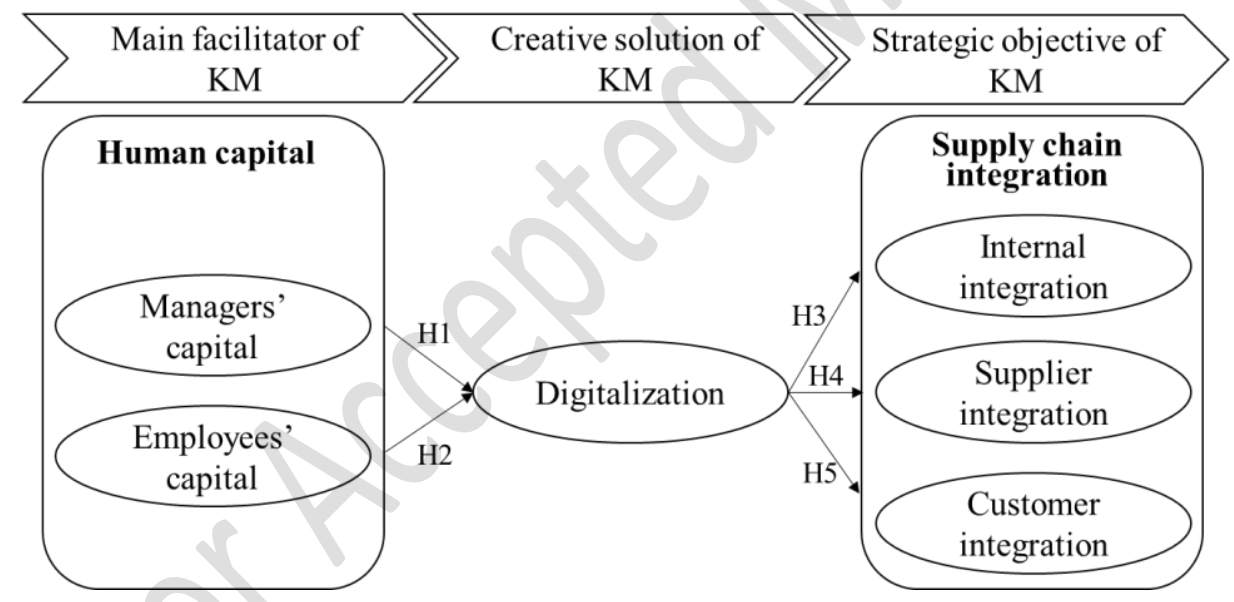

Figure 2. Conceptual Model

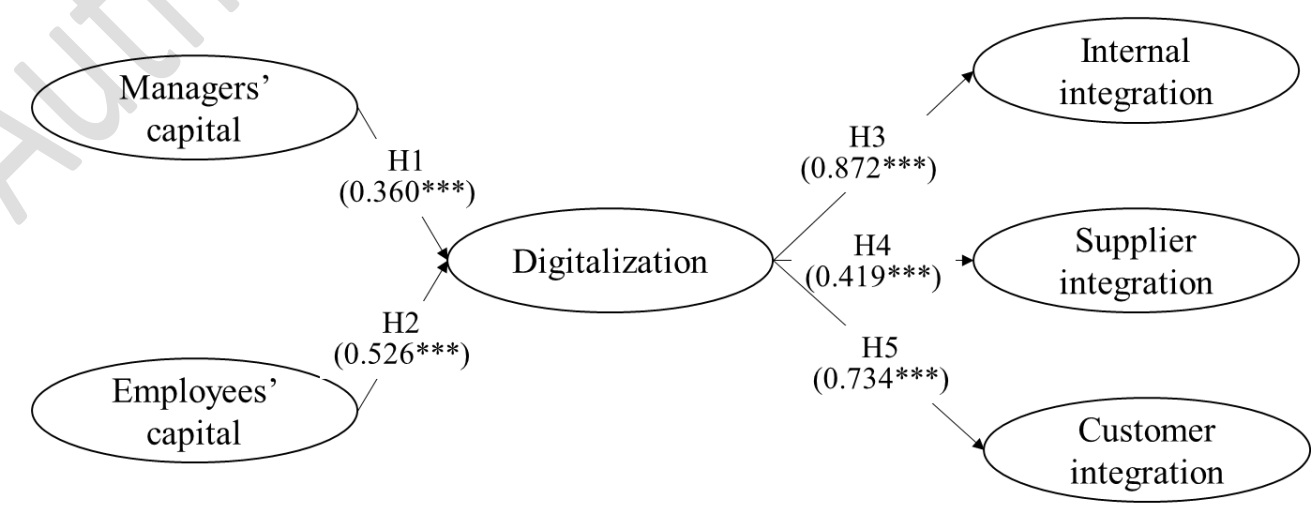

Note: Solid lines indicate significant relationships. ${ }^{*} \mathrm{p}<0.10 ; * * \mathrm{p}<0.05 ; * * * \mathrm{p}<0.01$

Figure 3. The Estimated Results of the SEM Model 
Table 1. Profile of the Respondents and Their Firms

Total (\%)

$(\mathrm{n}=188)$

Respondent's position (\%)

Top manager

8.0

Middle manager

61.7

Senior staff

30.3

Age of the firm (in number of years)

Less than 5

15.5

5-10

27.5

$11-15$

16.0

16-20

12.8

More than 20

28.2

Annual revenue (in millions of $\mathrm{RMB}$ )

Less than 50

13.3

$50-100$

12.2

$100-200$

10.1

200-2000

35.1

More than 2000

Ownership of the firm (\%)

State-owned

50.5

Local private

37.2

Foreign

5.3

Joint venture

6.9

Sector type (multiple choice) (\%)

Manufacturing

31.9

Commodity circulation

21.8

E-commerce

9.6

others

42.0

The proportion of staff aged 25-40 (\%)

$<20$

$21-40$

17.0

41-60

41.5

$61-80$

22.9

$>80$

15.4

The proportion of staff with a bachelor's degree

or higher $(\%)$

$<20$

21-40

19.7

41-60

13.3

61-80

22.9

$>80$

38.8 
Table 2. Reliability, Validity, Mean, Standard Deviation, and Correlation

\begin{tabular}{lrrrrrr}
\hline & 1 & 2 & 3 & 4 & 5 & 6 \\
\hline 1. Managers' capital & $\mathbf{0 . 7 7 7}$ & & & & & \\
2. Employees' capital & 0.217 & $\mathbf{0 . 7 6 6}$ & & & & \\
3. Digitalization & 0.229 & 0.159 & $\mathbf{0 . 7 9 9}$ & & & \\
4. Internal integration & 0.361 & 0.379 & 0.188 & $\mathbf{0 . 8 0 1}$ & & \\
5. Supplier integration & 0.393 & 0.280 & 0.352 & 0.290 & $\mathbf{0 . 7 8 8}$ & \\
6. Customer integration & 0.353 & 0.278 & 0.204 & 0.300 & 0.210 & $\mathbf{0 . 7 9 6}$ \\
Mean & 4.000 & 3.836 & 3.866 & 3.629 & 3.568 & 3.797 \\
SD & 0.850 & 0.762 & 0.815 & 0.892 & 0.837 & 0.801 \\
Cronbach's $\alpha$ & 0.841 & 0.886 & 0.862 & 0.872 & 0.837 & 0.895 \\
Composite reliability & 0.898 & 0.893 & 0.895 & 0.915 & 0.906 & 0.911 \\
\hline Note: Numbers on the diagonal are the square roots of the AVE values. *p $<0.05 ; * \mathrm{p}<0.01 ; * * * \mathrm{p}<0.001$
\end{tabular}




\section{Appendix. Construct Measurement}

Managers'capital (Song et al., 2020; Shou et al., 2018; Prajogo and Oke, 2016)

In the firm, managers...

make sure the workforce has the skills for the future

have professional ability and digital-savvy skill

engage actively in a digital transformation

promote a culture of innovation and change

ensure collaboration between internal units on digital transformation initiatives

have good relationship with their supply chain partners

Employees'capital (Song et al., 2020; Flothmann et al., 2018; Wilkesmann and Wilkesmann, 2018)

In the firm, employees...

have high-level skills in their respective jobs

have useful experiences about their own routine duty

deeply involved in developing digital initiatives than during past change efforts

are willing to contribute with ideas for organizations

are willing to cooperate with other departments' staff

have good relationship with their supply chain partners

Digitalization (Schniederjans et al., 2019; Kosmol et al., 2019; Büyüközkan and Göçer, 2018)

To accomplish digitalization, firms...

have clear digital goals and specific investment for digital strategy in annual budget

establish at least one new way of working, such as continuous learning or open work environments

standard operating processes are modified to include new digital technologies

provide digital products/ service to meet their customers' personalized needs

implement digital self-serve technologies for employees, business partners, customers to use

Internal integration (Feyissa et al., 2019; Macarena et al., 2018)

As OC retailers, firms...

have integrated information system among different departments/channels

share real-time operational data among departments/channels

develop mechanisms for internal information sharing and confidentiality

implement process integration, such as integrated warehousing and distribution

create network of cross-functional teams to corporate decision-making mechanisms

have efficient collaboration among departments/channels

Supplier integration (Wiengarten et al., 2019; Delic et al., 2019; Rajesh and Margaret, 2019)

As OC retailers, firms...

share real-time operational information with their suppliers

share performance matric with their suppliers

have common information systems or a unified data interface with their suppliers

design business processes with their suppliers jointly

maintain long-term relationship with their suppliers

establish a stable cooperative relationship with their suppliers

Customer integration (Wiengarten et al., 2019; Chen et al., 2018; Macarena et al., 2018) 
As OC retailers, firms...

have customer-oriented information platforms to display products provide service of order visualization to customers

have agile response to customers' orders

provide convenient feedback ways to customers

make demand forecast with customers jointly

have a perfect customer relationship management system 